\title{
PENGARUH LATIHAN JUMP TO BOX TERHADAP POWER OTOT TUNGKAI EKSTRAKULIKULER BOLABASKET
}

\author{
I Gede Dharma Utamayasa \\ Jurusan Pendidikan Jasmani, Universitas Adi Buana, Surabaya, Indonesia \\ dharmautamayasa92@gmail.com
}

(Received: August 2019 / Revised: September 2019 / Accepted: November 2019)

\begin{abstract}
ABSTRAK: Penelitian ini bertujuan untukk menguji tentang pengaruh latihan jump to box terhadap power otot tungkai. Populasi penelitian ini sebanyak 20 Orang yang berjenis kelamin laki-laki dibagi dalam dua kelompok. Kelompok eksperimen mendapat perlakuan latihan jump to box, kelompok eksperimenn II latihan konvensional. Jenis penelitian ini menggunakan penelitian kuantitatif dengan metode pretestposttest control group design. Rancangan penelitian menggunakan matching only design, serta analisis data menggunakan uji-t. Proses pengambilan data menggunakan Jump $d f$ (meter) untuk mendapatkan data power otot tungkai pada saat pretest dan posttest. Hasil dari penelitian ini yaitu terdapat pengaruh yang signifikan atau perbedaan antara data pretest dan posttest dari masing-masing variabel terikat baik pada kelompok eksperimen I maumpun kemlompok eksperimen II. Disimpulkan bahwa Latihan pliometrik jump to box berpengaruh terhadap tinggi lompatan yang dimana tinggi lompatan ini merupakan tolak ukur daya ledak otot tungkai khususnya pada cabang olahraga bolabasket.

KATA KUNCl: Jump to box, power otot tungkai, bolabasket.
\end{abstract}

ABSTRACTS: This study aims to examine the effect of jump to box exercise on leg muscle power. The population of this study were 20 male students who were divided into two groups. Experiment I group received jump to box training, experimental group II conventional exercise. This type of research uses quantitative research with the pretest-posttest control group design method. The research research design uses matching only design, as well as data analysis using t-test. The data collection process was carried out by Jump df for power to obtain data on leg muscle power at the pretest and posttest. The above data can be concluded that there is a significant influence of the jump to box exercise program on leg muscle power, especially in basketball sports.

KEYWORD:

Jump to box, power leg muscle, basketball.

\section{PENDAHULUAN}

Olahraga merupakan suatu kebutuhan bagi manusia karena manusia dalam melakukan aktivitasnya tidak pernah terlepas dari proses gerak, sebab tidak adaa kehidupan tanpa adanya gerakan. Begitu besar peran olahraga terhadap kehidupan manusia, sehingga olahraga dapat dijadikan sebagai sarana atau media untuk berekreasi, mata pencharian, pendidikan, kesehatan, kebudayaan bahkan sebagai sarana untuk mencapai prestasi. Pembinaan dan pengembangan olahraga merupakan bagian dari upaya peningkatan kesehatan jasmani dan rohani seluruh masyarakat, pemupukan watak, disiplin dann sportivitas, serta pengembangan prestasi olahraga yang dapat membangkitkan kebanggaan nasional (Zulfikar dkk, 2015).

Kapasitas performa atlet dan individu yang dilatih secara mandiri adalah tujuan utama dalam kinerja olahraga. Peningkatan juga ditentukan dari model latihan. Salah satu model latihan yang digunakan adalah plyometric. Latihan plyometric sangat efisiensi karena latihan plyometric dapat membantu meningkatkan pencapaian kondisi prima dalam olahraga. Plyometric dapat digunakan oleh atlet di semua jenis olahraga, 
dengan tujuan untuk meningkatkan kebugaran. Hal ini didukung oleh penelitian dari Khadijeh Iranoutst et al (2014) menyimpulkan bahwa sifat latihan plyometric menunjukkan peningkatan yang signifikan dalam kinerja kebugaran fisik salah satunya yaitu power otot tungkai.

Latihan plyometric adalah SSC (stretch shortening cycle) dimulai dari kontraksi panjangnya otot unit tendon yang mana diikuti langsung dengan kontraksi memperpendeknya otot. Kusnanik, dkk, 2011 mengatakan bahwa plyometric merupakan peregangan reflek untuk memfasilitasi rekruitmen dari otot unit, kontraksi accentric dimaksudkan untuk membentuk energi elastik dan kontraktil komponen otot saat meregang, langsung diikuti kontraksi concentric. Latihan yang menggabungkan kekuatan dan kecepatan untuk menghasilkan power yang melibatkan lebih banyak serat otot untuk menghasilkan spindle otot itu dinamakan latihan plyometric.

Adapun fase plyometric (Chu \& Myer, 2013) yaitu: Loading Phase yaitu tahap awal gerakan plyometric, yang dalam melibatkan pemanjangan otot yang cepat, disebut fase pemuatan. Fase ini juga telah diberi label dengan banyak istilah lain termasuk eksentrik. Coupling Phase yaitu tahap transisi antara fase pemuatan (kerja negatif) dan fase pembongkaran (kerja yang positif) dari latihan plyometric dapat digambarkan sebagai fase kopling. Fase ini biasa disebut sebagai fase amortisasi dan juga telah disebut fase transmisi. Tahap kopling adalah fase definitif latihan plyometric yang pada akhirnya menentukan efek sinergis yang diperoleh dari SSC. Jika transisi antara bongkar muat fase tidak terus-menerus dan cepat, tertunda dan kopling terputus-putus akan terjadi, dan energi yang didapat akan hilang dan hilang sebagai panas. Unloading Phase yaitu tahap akhir dari kegiatan plyometric juga telah disebut rebound, memperpendek, push-off, atau fase propulsi. Tahap muat latihan plyometric terjadi segera setelah fase kopling dan melibatkan pemendekan unit tendon otot. Unloading phase dimulai pada awal gerakan ke atas dan berakhir ketika jari-jari kaki tidak lagi kontak dengan tanah. Fase ini sering dianggap sebagai hasil atau fase yang dihasilkan, karena ini merupakan bagian dari mekanisme yang timbul selama fase pemuatan berkontribusi untuk peningkatan efisiensi produksi kekuatan. Penurunan energi elastis yang tersimpan terjadi pada coupling phase berlangsung lebih dari 25 milidetik. Durasi ratarata coupling phase untuk melompat telah dihitung menjadi 23 milidetik, dan waktu coupling yang ideal mungkin kurang dari 15 milidetik.

Sekolah merupakan sasaran atau tempat yang strategis untuk pencarian bibit-bibit olahragawan dengan dilakukannya pembinaan peningkatan prestasi olahraga untuk masa depan dan seolah menjaring bibit olahragawan yang nantinya diharapkan dapat berperstasi secara maksimal dimasa datang.

Performa siswa yang semakin meningkat diharapkan akan mampu memperoleh prestasi yang gemilang terutama di bidang olahraga. Plyometrik merupakan suatu metode latihan yang umum digunakan banyak pelatih olahraga untuk meningkatkann performa atlet terutama pada kekuatan otot tungkai.

Dalam upaya pembinaan prestasi olahraga, selain kekuatan, salah satu komponenn fiisk yang sangat penting dalam upaya tercapainya prestasi optimal adalah power otot tungkai, karena hampir semua cabang olahraga memerlukan power khususnya power otot tungkai dalam semua gerakan khususnya cabang olahraga bolabasket. Latihan dilakukan untuk meningkatkan power otot tungkai harus pula ditunjukan pada otot-otot tungkai secara khusus. Bentuk gerakan latihan yang digunakan dalam penelitian ini adalahh jump to box. Bentuk latihan tersebut dipilih karena 
latihan tersebut melibatkan otot-otot yang terlibat dalam power otot tungkai.

Progra latihan Jump to box belum dilatihkan atau diakukan di ekstrakulikuler khususnya pada cabang olahraga bolabasket. Atas dasar tersebut tertarik melakukan penelitian yag terfokus pada power otot tungkai dengan menggunakan latihan jump to box. Selain itu juga ingin membuktikan bahwa program latihan ini dapat meningkatkan power otot tungkaipada ekstrakulikuler bolabasket di SMA Kristen Pringadi Surabaya.

\section{METODE PENELITIAN}

Jenis penelitian dalam penelitian ini adalah jenis eksperimen dengan menggunakan metode pretest-posttest control group design (Sugiyono, 2008). Desain ini dilakukan dengan mengukur subyek penelitian (pretest) sebelum diadakannya perlakuan (treatment) dan melakukan pengukuran kembali setelah diberii perlakuan (posttest), adapun tujuan penelitian yaitu untuk menguji keabsahan suatu teori atau ilmu pengetahuan dan padaa hasil akhir peneliti akan menghasikan gagasan baru.

Populasi dalam penelitian ini adalah seluruh peserta ekstrakulikuler bolabasket Sekolah Menengah Atas Kristen Pringadi Surabaya yang berjumlah 20 siswa laki-laki. Sampel dikelompokan secara ordinal pairing, kelompok I menggunakan latihan jump to box sedangkan kelompok II latihan konvensional. Instrument power otot tungkai adalah dengan menggunakan jump DF.

Jenis data yang akan dikumpulkan dalam penelitian ini adalah tinggi lompatan. Analisis data menggunakan teknik statistic deskritif dan dianalisis dengan bantuan program computer SPSS (Statistical Program For Social Science) 22.
3. HASIL

Untuk mengetahui pengaruh latihan jump to box maka langkah pengujiannya menggunakan $u j i-t$ yang dalam SPSS disebut sebagai paired $t$ test. Adapun hasil pengolahan datanya pada table di bawah ini:

Tabel 1. Kelompok Pre-test

\begin{tabular}{|c|c|c|c|c|}
\hline \multicolumn{5}{|c|}{ Paired Samples Test } \\
\hline & & Mean & $t$ & Sig.(2tailed) \\
\hline $\begin{array}{l}\text { K1- } \\
\text { K2 }\end{array}$ & $\begin{array}{l}\text { Pre-test K1 } \\
\text { Pre-test K2 }\end{array}$ & 145.00 & 3.031 & 0.007 \\
\hline
\end{tabular}

Tabel 2. Kelompok Post-test

\begin{tabular}{|c|c|c|c|c|}
\hline \multicolumn{5}{|c|}{ Paired Samples Test } \\
\hline & & Mean & $t$ & Sig.(2tailed) \\
\hline $\begin{array}{l}\text { K1- } \\
\text { K2 }\end{array}$ & $\begin{array}{l}\text { Post-test } \mathrm{K} 1 \\
\text { Post-test } \mathrm{K} 2\end{array}$ & 145.00 & 3.181 & 0.005 \\
\hline
\end{tabular}

Berdasarkan dari kedua table diatas, menunjukan bahwa tingkat signifikansi dari masing-masing variabel diperoleh sig $<0,05$ dengan demikian terdapat pengaruh yang signifikan atau perbedaan antara data pretest dan posttest dari masing-masing variabel terikat baik pada kelompok eksperimen I maumpun kemlompok eksperimen II. Jadi dapat disimpulkan bahwa ada perbedaan setelah diberi program latihan jump to box terhadap peningkatan power otot tungkai.

\section{PEMBAHASAN}

Jump to box merupakan latihan melompat untuk meningkatkan intensitas melompat dengan menggunakan sebuah kotak dengan menggunakan kedua tungkai bersama-sama. Terkait dengan uraian tersebut, terdapat interaksi antara latihan jump to box terhadap peningkatan power otot tungkai. Ketinggian kotak bergantung pada ukuran atlet, permukaan, arahan dan tujuan program. Kotak latihan ini mungkin melibatkan satu atau lebih bahkan bias bergantian kaki (Baechle, 2008). Hasil penelitian yang dilakukan Mufidatul Hasanah dalam penelitiannya didapatkan hasil bahwa latihan plyometric box 
Journal of Sport and Exercise Science, Vol 2, No 2, 2019 (55-59)

Pengaruh Latihan Jump To Box Terhadap Power Otot Tungkai Ekstrakulikuler Bolabasket

jump berpengaruh lebihh baik terhadap power otot tungkai pada atlet bolavoli klub Tugumuda Kota Semarang. Peningkatan untuk kelompok eksperimenn I (depth jump) sebesar $8.3 \%$ dan termasuk dalam kategori rendah, peningkatan untuk kelompok eksperimen 2 (jump to box) sebesar $53.5 \%$ termasuk dalam kategori sedang. Di dalam jurnal IPTEK olahraga yang ditulis oleh Sri Haryono, dkk (2013:4) disebutkan bahwa semakin tinggi lompatan dianggap semakin besar pula power tungkai yang dimiliki atlet tersebut.

Latihan pliometrik jump to box berpengaruh terhadap tinggi lompatan yang dimana tinggi lompatan ini merupakan tolak ukur daya ledak otot karena secara fisologi terjadi reflek regang (stretch reflex) atau reflek myotic merupakan respon terhadap tingkat peregangan otot yang diberikan dan merupakan salah satu reflek tercepat pada tubuh manusia, karena ada hubungan langsung antara receptor sensorik dalam otot (muscle spindle) dengan sumsum tulang belakang serta otot yang bersangkutan.

Latihan plyometric jump to box berpengaruh terhadap tinggi lompatan yang dimana tinggi merupakan tolak ukurr power otot tungkai. Jump to box merupakan latihan dengan intensitas rendah. Pada latihan atlet melompat untuk meningkatkan intensitas melompat dan melompat dengan menggunakan sebuah kotak dengan menggunakan kedua tungkai bersamasamaa (Baechle, 2008). Menurut beberapa penelitian latihan plyometric jump to box sangat baik untuk meningkatakan power otot tungkai. Salah satu penelitian yang dilakukan oleh Romey Hadi tahun 2010 membuktikan bahwa latihan plyomeric jump to box biasanya digunakan untuk meningkatkan tinggi lompatan pada atlet. Sebagai kita ketahui, salah satu teknik latihan plyometric yang banyak digunakan atlet untuk meningkatkan power otot tungkai adalah jumping, jenis dari latihannya sendiri adalah jump to box.

\section{SIMPULAN DAN REKOMENDASI}

Berdasarkan hasil dan pembahasan di atas maka dapat disimpulkan bahwa latihan jump to box berpengaruhh yang signifikan terhadap power otot tungkai pada pemain basket di Sekolah Menengah Atas Krsiten Pringadi Surabaya.

\section{REFERENSI}

Baker,DG, Newton RU. 2008. " Comparison of Lower Body Strength, Power, Accelera-tion, Speed, Agility, and Sprint Momentum to Describe and Compare Playing Rank among Professional Rugby League Players". J Strength Cond Res.22(1): 153-158.

Baechle, T. R. 2008. Essentials Strength Of And Training Conditioning: Human Kinetics.

Cormie ,P, McGuigan MR, Newton RU. 2010. "Adaptations in Athletic Performance after Ballistic Power versus Strength Training". Med Sci Sports Exerc, 42(8), pp: 1582-1598.

Donald A Chu. (2013). Plyometrics. United States: Human Kinetics.

Khadijeh I and Morteza T. (2014). "Effects of 8 week plyometric and strengthening training programme on selected physical fitness factors of elite kabaddi players". Journal of fundamental and applied life sciences issn:2231- 6345, vol.4(s4),pp.3942-3948.

Kusnanik,N.W., Nasution,J., dan Hartono,S. (2011). Dasar-dasar Fisiologi Olahraga.Unesa: Unesa University Press.

Mufidatul. 2013. Pengaruh Latihan Pliometrik Depth Jump Dan Jump To Box Terhadap Power Otot Tungkai Pada Atlet Bolavoli Klub Tugumuda Kota Semarang. Universitas Negeri Semarang.

Roesdiyanto dan Budiwanto, S. 2008. Dasar-dasar Kepelatihan Olahraga. Malang: Laboratorium IImu Keolahragaan, Jurusan IImu Keolahragaan, Universitas Negeri Malang.

Romei, 2010. Perbedaan pengaruh hasil latihan plyometric antara squat depth jump dan 
jump to box terhadap peningkatan daya ledak otot tungkai Gemolong Sragen, Surakarta: Universitas Sebelas Maret.

Sukadiyanto dan Muluk, D. 2011. "Pengantar Teori dan Metedologi Melatih Fisik". Bandung : CV. LUBUK AGUNG.

Sri Haryono, Feddy Setio Pribadi dan Anggit W. "Pengembangan Jump Power Meter Sebagai Alat Pengukur Power Tungkai". Jurnal IPTEK Olahraga. 2013:1-17.

Zulfikar, Hendtik Mentara, Hasdin. 2015. "Pengaruh Latihan Multiple Jump To Box Terhadap Kemampuan Menendang Bola Dalam Permainan Sepak Bola Pada Club Persito Tolitoli". E-Journal Tadulakoo Physical Education, Health andd Recreation, Volume 3, Nomor 12 oktober-Desember 2015 ISSN 2337-4535 